\title{
Acetylcholinesterase Measurement
}

National Cancer Institute

\section{Source}

National Cancer Institute. Acetylcholinesterase Measurement. NCI Thesaurus. Code C96560.

The determination of the amount of acetylcholinesterase present in a sample. 